\title{
PENERAPAN ASAS KEADILAN DAN KEPASTIAN HUKUM TERHADAP PAJAK PENGHASILAN FINAL BAGI USAHA KECIL
}

\author{
Sudjana \\ Fakultas Hukum, Universitas Padjadjaran \\ Email: sudjana@unpad.ac.id
}

Diterima : 03 Sep 2020| Direvisi : 29 Sep 2020| Disetujui : 15 Okt 2020| Diterbitkan : 14 Des 2020

\begin{abstract}
This study aims to determine the application of the principle of justice and legal certainty towards Final Income Taxes for Small Businesses. The method used is normative legal research, which uses library materials or secondary data through primary legal materials, secondary legal materials, and tertiary legal materials. Data collection techniques by means of document studies, and data analysis are carried out through qualitative normative. The results of the study show that the imposition of final PPh for small businesses is in line with the principle of benefit because it makes it easier for small business taxpayers to repay their income tax without having to make financial statements in detail, but not in accordance with the principle of justice because they do not pay attention in the tax law, and is inconsistent so that it does not reflect the principle of legal certainty, given that the final PPh regulation is regulated by Article 4 paragraph (2) letter a / d Law No. 36 of 2008 concerning Income tax, then the addition of the final PPh object in Article 4 paragraph (2) letter e is regulated through $P P$. This is not in accordance with the characteristics of the PP which cannot increase or reduce the provisions of the Act.
\end{abstract}

Keywords: Justice, Certainty, Tax, Small Business

\begin{abstract}
ABSTRAK
Kajian ini bertujuan untuk menentukan penerapan asas keadilan dan kepastian hukum terhadap Pajak Penghasilan Final bagi Usaha Kecil. Metode yang digunakan adalah penelitian hukum normatif, yang menggunakan bahan pustaka atau data sekunder melalui bahan hukum primer, bahan hukum sekunder, dan bahan hukum tersier. Teknik pengumpulan data dengan cara studi dokumen, dan analisis data dilakukan melalui normatif kualitatif. Hasil kajian menunjukan Pengenaan PPh final bagi usaha kecil sejalan dengan asas kemanfaatan karena memudahkan WP usaha kecil untuk melunasi PPhnya tanpa harus membuat laporan keuanga secara detail, tetapi tidak sesuai dengan asas keadilan karena tidak memperhatikan daya pikul wajib pajak (usaha kecil yang bersangkutan) sebagaimana disyaratkan dalam undang-undang perpajakan, dan tidak konsisten sehingga tidak mencerminkan asas kepastian hukum mengingat pengaturan $\mathrm{PPh}$ final diatur dalam undang-undang via Pasal 4 ayat (2) huruf a s/d UU No 36 Tahun 2008 tentang pajak Penghasilan, selanjutnya penambahan obyek PPh final dalam Pasal 4 ayat (2) huruf e diatur melalui PP. Hal ini tidak sesuai dengan karakteristik PP yang tidak dapat menambah atau mengurangi ketentuan UU.
\end{abstract}

Kata kunci : Keadilan, kepastian hukum, Pajak, Usaha kecil 


\section{PENDAHULUAN}

Pasal 23A UUD Tahun 1945 mengatakan bahwa "pajak dan pungutan lain yang bersifat memaksa untuk keperluan negara diatur dengan undang-undang," karena itu lahir Undang-Undang Republik Indonesia Nomor 36 Tahun 2008 tentang Perubahan Keempat Atas Undang-Undang Nomor 7 Tahun 1983 tentang Pajak Penghasilan yang didasarkan atas pertimbangan dalam rangka upaya mengamankan penerimaan negara yang semakin meningkat, mewujudkan sistem perpajakan yang netral, sederhana, stabil, lebih memberikan keadilan, dan lebih dapat menciptakan kepastian hukum serta transparansi perlu dilakukan perubahan terhadap Undang-Undang Nomor 7 Tahun 1983 tentang Pajak Penghasilan sebagaimana telah beberapa kali diubah terakhir dengan Undang-Undang Nomor 17 Tahun 2000 tentang Perubahan Ketiga atas Undang-Undang Nomor 7 Tahun 1983 tentang Pajak Penghasilan.

Ketentuan Pasal 4 ayat (2) huruf e UU No 36 Tahun 2008 jo Peraturan Pemerintah Nomor 46 Tahun 2013 mengatur PPh final untuk usaha kecil, yang selanjutnya Peraturan Pemerintah tersebut diubah oleh PP No 23 Tahun 2018 tentang Pajak Penghasilan atas Penghasilan dari Usaha yang diterima Atau diperoleh Wajib Pajak yang memiliki peredaran bruto tertentu. Alasan perubahan tersebut untuk mendorong masyarakat berperan serta dalam kegiatan ekonomi formal, dengan memberikan kemudahan dan lebih berkeadilan kepada Wajib Pajak yang memiliki peredaran bruto tertentu untuk jangka waktu tertentu. Penjelasan umum PP No 23 Tahun 2018 menjelaskan, "Dengan memperhatikan hasil evaluasi pelaksanaan Peraturan Pemerintah Nomor 46 Tahun 2013, untuk memberikan kemudahan dan kesederhanaan kepada Wajib Pajak dalam melaksanakan kewajiban perpajakannya, atas penghasilan dari usaha yang diterima atau diperoleh Wajib Pajak yang memiliki peredaran bruto tertentu dikenai Pajak Penghasilan yang bersifat final dengan jangka waktu tertentu. Pemberlakuan jangka waktu tertentu dimaksudkan sebagai masa pembelajaran bagi Wajib Pajak untuk dapat menyelenggarakan pembukuan sebelum dikenai Pajak Penghasilan dengan rezim umum."

Pertumbuhan usaha kecil di Indonesia dari tahun ke tahun semakin bertambah. Berdasarkan berita yang dilansir dari Kementerian Koperasi dan Usaha Kecil dan Menengah, pelaku usaha kecil telah mencapai 7\% dari total jumlah penduduk di Indonesia. Angka ini telah meningkat tajam dari tahun 2017 yakni sebesar 3,1\% (Hendri, 2018).

Usaha kecil di Indonesia memiliki peran yang sangat signifikan pada perekonomian nasional dan juga terbukti tangguh mampu bertahan dalam kondisi krisis (Hartarto \& Muhajir, 2013). Hal ini yang menjadikan usaha kecil termasuk dalam objek pajak yang potensial karena merupakan salah satu bentuk usaha yang paling sesuai bagi Indonesia sebab sifatnya yang padat karya dan selalu memanfaatkan potensi daerah sekitarnya (Aneswari, Darmayasa, \& Yusdita, 2015).

Usaha kecil merupakan sektor ekonomi yang mempunyai peran cukup besar dalam perekenomian nasional karena sifatnya yang padat karya dan selalu memanfaatkan potensi daerah sekitarnya (Aneswari, Darmayasa, \& Yusdita, 2015). Berdasarkan data Produksi Domestik Bruto (PDB) tahun 2011, Usaha kecil mempunyai kontribusi kurang lebih 57\% total PDB. Namun demikian apabila dibandingkan dengan kontribusi usaha kecil terhadap penerimaan pajak, terdapat missmatch yaitu kontribusi uaha kecil pada penerimaan perpajakan sangat kecil karena kurang lebih $0.5 \%$ dari total penerimaan pajak. Ketidak imbangan kontribusi usaha 
kecil tersebut merupakan suatu indikasi bahwa tingkat ketaatan usaha kecil dalam memenuhi kewajiban perpajakan masih sangat rendah (Pusat Kebijakan Pendapatan Negara-Badan Kebijakan Fiskal).

Dalam upanya untuk mendorong pemenuhan kewajiban perpajakan secara sukarela (voluntary tax compliance) serta mendorong kontribusi penerimaan negara dari usaha kecil, Pemerintah telah menerbitkan Peraturan Pemerintah Nomor 46 Tahun 2013 tentang Pajak Penghasilan atas Penghasilan dari Usaha yang diterima atau diperoleh Wajib Pajak yang memiliki Peredaran Bruto tertentu (Pusat Kebijakan Pendapatan Negara-Badan Kebijakan Fiskal). Dalam Peraturan Pemerintah ini diatur pengenaan Pajak Penghasilan (PPh) yang bersifat final atas penghasilan yang diterima atau diperoleh Wajib Pajak dengan batasan peredaran bruto tertentu. Ketentuan dalam Peraturan Pemerintah ini merupakan aplikasi dari model presumptive regime dalam perpajakan. Presumptive regime merupakan suatu bentuk pendekatan pengenaan pajak yang diterapkan dalam ekonomi yang pelakunyanya masih memiliki keterbatasan kemampuan administrasi dan pembukuan. Untuk itu perlu ada desain pemajakan khusus, dengan tujuan meminimalisir cost of compliance (Pusat Kebijakan Pendapatan Negara-Badan Kebijakan Fiskal).

Berdasarkan data BPS, usaha kecil memberikan kontribusi pada Produk Domestik Bruto (PDB) nasional yang cukup besar. Dalam periode tahun 2008 sampai dengan tahun 2011, kontribusi usaha kecil pada PDB nasional selalu di atas 50\% dari total PDB nasional. Pada tahun 2011, misalnya, nilai PDB nasional atas harga konstan tahun 2000 sebesar Rp. 2.277 triliun. Dari nilai PDB tersebut, peran usaha kecil tercatat sebesar Rp. 1.269.3 triliun atau 55,7\% dari total PDB nasional, sementara usaha besar berkontribusi sebesar Rp. 1.007,7 triliun atau 44,3\% (Pusat Kebijakan Pendapatan Negara-Badan Kebijakan Fiskal).

Kontribusi usaha kecil yang besar pada perekenonomian nasional tersebut, seharusnya juga berpotensi untuk meningkatkan pendapatan negara melalui pajak. Namun demikian data penerimaan pajak tahun 2005 sampai tahun 2012 menunjukkan, sebagian besar penerimaan pajak masih didominasi bukan oleh usaha kecil, melainkan oleh usaha besar. Pada tahun 2009 misalnya, pembayaran pajak usaha kecil hanya sebesar sebesar Rp.2,81 triliun, atau sebesar $0.5 \%$ dari total penerimaan pajak yang sebesar Rp565,77 triliun. Begitu juga pada APBN 2012, Pajak Penghasilan (PPh) nonmigas ditargetkan sebesar Rp445,7 triliun dan Pajak Pertambahan Nilai (PPN) ditargetkan sebesar Rp336,1 triliun, tetapi dari sebagian besar target tersebut direalisasi bukan dari usaha kecil melainkan dari usaha besar (Pusat Kebijakan Pendapatan Negara-Badan Kebijakan Fiskal).

Penerapan standard regime-simplified/reduced rate di Indonesia terlihat belum mampu mendorong voluntary compliance usaha kecil. Hal ini dapat dilihat dari indikasi adanya miss-match antara kontribusi usaha kecil pada PDB dengan kontribusi usaha kecil pada penerimaan pajak. Dengan memperhatikan karakteristik dari usaha kecil, maka perlu disusun stategi untuk meningkatkan compliance dari usaha kecil. Strategi terhadap kelompok usaha kecil yang memutuskan untuk tidak taat pada ketentuan (disengaged) adalah melalui penegakan hukum secara penuh, untuk memberi efek jera. Selanjutnya, Kelompok kedua yang tidak mau taat tetapi akan taat apabila pemerintah memberikan perhatian kepada mereka (resisters) adalah pencegahan melalui deteksi awal atas kecenderungan penghindaran pajak. Sedangkan kelompok yang mencoba untuk taat tetapi mengalami kesulitan untuk memenuhi ketentuan yang berlaku (tries). Strategi yang dapat dilakukan untuk kelompok ini 
adalah pemberian asistensi dan kemudahan agar dapat mentaati ketentuan. Untuk kelompok terakhir ini, upaya pengingkatan compliance dilakukan dengan memberikan kemudahan, agar menimbulkan ketaatan sukarela (IFC, 2007). Merujuk pada karakteristik bisnis, usaha kecil di Indonesia bercirikan masih belum mengerti pencatatan atau akuntansi, dan masih mengalami masalah dalam penyusunan laporan keuangan. Di sisi lain, dengan model standard regime yang berlaku diterapkan, dituntut bagi usaha kecil untuk menyediakan laporan keuangan yang memadai sebagai dasar menentukan PPh terutangnya.

Dengan kondisi tersebut menyebabkan usaha kecil akan mengalami kesulitan untuk menaati ketentuan perpajakan, dan berdampak pada rendahnya tingkat compliance, sehingga menimbulkan tingginya cost of compliance bagi Wajib Pajak (Pusat Kebijakan Pendapatan Negara-Badan Kebijakan Fiskal). Dengan demikian, pengenaan pajak terhadap usaha kecil yang mempunyai niat untuk taat pada peraturan, menjadi terhambat karena untuk dapat mentaati ketentuan perpajakan berada di atas kemampuannya. Oleh karena itu, perlu kebijakan untuk mensintesiskan terhadap 2 (dua) kepentingan yang bertolak belakang yaitu dengan cara menerapkan sistem yang memudahkan usaha kecil dalam memenuhi kewajiban perpajakannya melalui pengenaan PPh final, artinya usaha kecil yang memenuhi persyaratan dikenakan tarif $\mathrm{PPh}$ tertentu yang dikenakan atas peredaran bruto (omzet) usaha sebesar Rp 4,8 miliar dalam 1 tahun pajak terakhir, tanpa memperhatikan kewajiban pelaporan keuangan secara detail. Namun, kebijakan dalam UU PPh tersebut perlu dikaji berkaitan dengan asas keadilan dalam arti proporsional dan kepastian hukum yang mencerminkan bahwa substansi hukum tidak bertentangan dengan ketentuan yang lebih tinggi, tidak ambigu, tegas, dan jelas sehingga memudahkan para wajib pajak usaha kecil dalam menjalankan atau memenuhi hak dan kewajibannya secara baik menurut perundangundangan perpajakan.

Kajian ini bertujuan untuk menentukan penerapan asas keadilan dan kepastian hukum melalui asas-asas yang berlaku dalam perpajakan setelah perubahan PP No 46 Tahun 2013 oleh PP No 23 Tahun 2018.

\section{METODE PENELITIAN}

Kajian ini merupakan penelitian hukum normatif atau penelitian kepustakaan (Depri Liber Sonata, 2014:30), yang menggunakan bahan pustaka atau data sekunder melalui bahan hukum primer, bahan hukum sekunder, dan bahan hukum tersier. Teknik pengumpulan data dengan cara studi dokumen, yaitu meneliti dokumen perundang-undangan berkaitan dengan obyek yang dibahas. Metode analisis data dilakukan melalui normatif kualitatif, yaitu menganalisis data berdasarkan norma dari peraturan perundang-undangan melalui interpretasi tidak menggunakan data statistik.

\section{HASIL PENELITIAN}

Ketentuan Pasal 4 ayat (2) UU No 36 Tahun 2008 tentang PPh menyatakan: Penghasilan di bawah ini dapat dikenai pajak bersifat final:

a. penghasilan berupa bunga deposito dan tabungan lainnya, bunga obligasi dan surat utang negara, dan bunga simpanan yang dibayarkan oleh koperasi kepada anggota koperasi orang pribadi;

b. penghasilan berupa hadiah undian; 
c. penghasilan dari transaksi saham dan sekuritas lainnya, transaksi derivatif yang diperdagangkan di bursa, dan transaksi penjualan saham atau pengalihan penyertaan modal pada perusahaan pasangannya yang diterima oleh perusahaan modal ventura;

d. penghasilan dari transaksi pengalihan harta berupa tanah dan/atau bangunan, usaha jasa konstruksi, usaha real estate, dan persewaan tanah dan/atau bangunan; dan

e. penghasilan tertentu lainnya, yang diatur dengan atau berdasarkan Peraturan Pemerintah.

Peraturan pemerintah yang dimaksud dalam Pasal 4 ayat (2) huruf e adalah PP No 46 Tahun 2013 yang diubah oleh PP No 23 Tahun 2018. Apabila dibandingkan kedua PP tersebut, maka dapat dilihat sebagai berikut (https://www.kawanpajak. com/2018/08/perbandingan-pp-46-vs-pp-23.html):

\begin{tabular}{|c|c|c|}
\hline & PP No 46 Tahun 2013 & PP No 23 Tahun 2018 \\
\hline Subjek Pajak & $\begin{array}{l}\text {-WP Orang Pribadi } \\
\text {-WP Badan tidak } \\
\text { termasuk BUT }\end{array}$ & $\begin{array}{l}\text {-Wajib Pajak Orang } \\
\text { Pribadi } \\
\text {-WP Badan tertentu } \\
\begin{array}{cl}\text { 1. } & \text { PT } \\
\text { 2. } & \text { CV dan Firma } \\
\text { 3. } & \text { Koperasi }\end{array}\end{array}$ \\
\hline $\begin{array}{l}\text { Pengecualian Subjek } \\
\text { Pajak }\end{array}$ & $\begin{array}{l}\text { Wajib Pajak orang pribadi } \\
\text { yang melakukan kegiatan } \\
\text { usaha perdagangan dan/atau } \\
\text { jasa yang dalam usahanya } \\
\text { menggunakan: } \\
\text { 1. sarana atau prasarana yang } \\
\text { dapat dibongkar pasang, } \\
\text { baik yang menetap } \\
\text { maupun tidak menetap; } \\
\text { dan sebagian atau seluruh } \\
\text { tempat untuk kepentingan } \\
\text { umum yang tidak } \\
\text { diperuntukkan bagi } \\
\text { tempat usaha atau } \\
\text { berjualan } \\
\text { Wajib Pajak badan yang: } \\
\text { 1. belum beroperasi secara } \\
\text { komersial; atau } \\
\text { 2. dalam jangka waktu } 1 \\
\text { tahun setelah beroperasi } \\
\text { secara komersial } \\
\text { memperoleh peredaran } \\
\text { bruto melebihi Rp4,8M }\end{array}$ & $\begin{array}{l}\text { 1. Wajib Pajak yang } \\
\text { memilih untuk dikenai } \\
\text { PPh berdasarkan tarif } \\
\text { Pasal } 17 \text { ayat (1) huruf } \\
\text { a, Pasal } 17 \text { ayat (2a), } \\
\text { atau Pasal } 31 \mathrm{E} \text { UU } \\
\text { PPh } \\
\text { 2. persekutuan } \\
\text { komanditer atau firma } \\
\text { yang dibentuk oleh } \\
\text { beberapa Wajib Pajak } \\
\text { orang pribadi yang } \\
\text { memiliki keahlian } \\
\text { khusus menyerahkan } \\
\text { jasa sejenis dengan } \\
\text { jasa sehubungan } \\
\text { dengan pekerjaan } \\
\text { bebas } \\
\text { 3. WP Badan yang } \\
\text { memperoleh fasilitas } \\
\text { Psl } 31 \text { A UU PPh dan } \\
\text { PP 94 U4 Tetap }\end{array}$ \\
\hline
\end{tabular}




\begin{tabular}{|c|c|c|}
\hline Batasan Omzet & \multicolumn{2}{|c|}{$\begin{array}{l}\text { Menerima penghasilan dari usaha, tidak termasuk } \\
\text { penghasilan dari jasa sehubungan dengan pekerjaan bebas, } \\
\text { dengan peredaran bruto tidak melebihi Rp } 4,8 \mathrm{M} \text { dalam } 1 \\
\text { Tahun Pajak. }\end{array}$} \\
\hline $\begin{array}{l}\text { Pengecualian obyek } \\
\text { pajak }\end{array}$ & \multicolumn{2}{|c|}{$\begin{array}{l}\text { a. Penghasilan yang diterima atau diperoleh dari jasa } \\
\text { sehubungan dengan pekerjaan bebas; } \\
\text { b. Penghasilan yang diterima atau diperoleh diluar } \\
\text { negeri; } \\
\text { c. Usaha yang atas penghasilannya telah dikenai Pajak } \\
\text { Penghasilan yang bersifat final dengan ketentuan } \\
\text { peraturan perundang-undangan perpajakan tersendiri; } \\
\text { dan } \\
\text { d. Penghasilan yang dikecualikan sebagai objek pajak }\end{array}$} \\
\hline Tarif & $1 \%$ & $0,5 \%$ \\
\hline Batasan Waktu & Tidak ada & $\begin{array}{l}\text { 1. WP OP : } 7 \text { tahun } \\
\text { 2. CV/Firma/Koperasi: } 4 \\
\text { tahun } \\
\text { 3. PT : } 3 \text { tahun } \\
\text { dihitung sejak: } \\
\text { WP lama : Tahun } \\
\text { Pajak PP Berlaku } \\
\text { WP Baru :Tahun } \\
\text { Pajak terdaftar }\end{array}$ \\
\hline
\end{tabular}




\begin{tabular}{|l|l|l|}
\hline $\begin{array}{l}\text { Penentuan } \\
\text { Pengenaan Pajak }\end{array}$ & $\begin{array}{l}\text { Didasarkan pada peredaran } \\
\text { bruto dari usaha dalam 1 tahun } \\
\text { dari Tahun Pajak terakhir } \\
\text { sebelum Tahun Pajak yang } \\
\text { bersangkutan. }\end{array}$ & $\begin{array}{l}\text { Tetap. } \\
\text { yang status Pisah harta } \\
\text { dan Memilih Terpisah (2 } \\
\text { NPWP) harus } \\
\text { berdasarkan } \\
\text { penggabungan sesuai } \\
\text { prinsip keluarga sebagai } \\
\text { satu kesatuan ekonomis }\end{array}$ \\
\hline DPP & Peredaran bruto tiap bulan & $\begin{array}{l}\text { Peredaran bruto tiap } \\
\text { bulan }\end{array}$ \\
& & \multicolumn{2}{|c|}{} \\
\hline
\end{tabular}

Alasan perubahan PP tersebut untuk lebih menjamin dan mendorong masyarakat berperan serta dalam kegiatan ekonomi formal, memberikan kemudahan dan lebih berkeadilan kepada Wajib Pajak yang memiliki peredaran bruto tertentu untuk jangka waktu tertentu, memberikan kesempatan berkontribusi bagi negara, dan pengetahuan manfaat pajak bagi masyarakat (Kementrian Keuangan Republik Indonesia, Dirktorat Jenderal Pajak). Selanjutnya, dengan memperhatikan hasil evaluasi pelaksanaan Peraturan Pemerintah Nomor 46 Tahun 2013, untuk memberikan kemudahan dan kesederhanaan kepada Wajib Pajak dalam melaksanakan kewajiban perpajakannya, atas penghasilan dari usaha yang diterima atau diperoleh Wajib Pajak yang memiliki peredaran bruto tertentu dikenai Pajak Penghasilan yang bersifat final dengan jangka waktu tertentu. Pemberlakuan jangka waktu tertentu dimaksudkan sebagai masa pembelajaran bagi Wajib Pajak untuk dapat menyelenggarakan pembukuan sebelum dikenai Pajak Penghasilan dengan rezim umum. Selain itu dalam tataran hukum, pemberlakuan jangka waktu tertentu terkait dengan aspek kepastian hukum.

PP No 46 Tahun 2013 yang diubah oleh PP No 23 tahun 2018 diperuntukan bagi wajib pajak yang tergolong usaha kecil. Usaha Kecil adalah usaha ekonomi produktif yang berdiri sendiri, yang dilakukan oleh orang perorangan atau badan usaha yang bukan merupakan anak perusahaan atau bukan cabang perusahaan yang dimiliki, dikuasai, atau menjadi bagian baik langsung maupun tidak langsung dari Usaha Menengah atau Usaha Besar yang memenuhi kriteria Usaha Kecil. Kriteria Usaha Kecil adalah sebagai berikut: a. memiliki kekayaan bersih lebih dari Rp50.000.000,00 (lima puluh juta rupiah) sampai dengan paling banyak Rp500.000.000,00 (lima ratus juta rupiah) tidak termasuk tanah dan bangunan tempat usaha; atau b. memiliki hasil penjualan tahunan lebih dari Rp300.000.000,00 (tiga ratus juta rupiah) sampai dengan paling banyak Rp2.500.000.000,00 (dua milyar lima ratus juta rupiah). Kriteria tersebut nilai nominalnya dapat diubah sesuai dengan perkembangan perekonomian yang diatur dengan Peraturan Presiden. 


\section{PEMBAHASAN}

\section{Penerapan Asas keadilan dalam Pengenaan PPh final bagi Usaha Kecil}

Keadilan diartikan sebagai pembagian yang konstan dan terus menerus untuk memberikan hak setiap orang. The constant and perpetual disposition to render every man his due. Keadilan menuntut agar tiap-tiap perkara harus ditimbang sendiri, Ius suum cui- que tribuere (Tata Wijayanta, 2014).

Keadilan sebagai tujuan hukum dikemukakan oleh filsuf Yunani, Aristoteles yang mengatakan "bahwa hukum mempunyai tugas yang suci, yaitu memberi kepada setiap orang yang berhak menerimanya" (Utrecht/ Moh Saleh Djindang). Secara teoritis dapat dikemukakan beberapa asas untuk menentukan sesuatu adil atau tidak adil, antara lain asas kebutuhan yang mengatakan setiap warga masyarakat mendapatkan bagian sesuai dengan keperluan yang nyata. John Rawls dalam $A$ Theory of justice, Political Liberalism, dan The Law of Peoples, memberikan pengaruh pemikiran cukup besar terhadap diskursus nilai-nilai keadilan (Pan Mohamad Faiz, 2009, Sudjana, 2017), John Rawls yang dipandang sebagai perspektif "liberalegalitarian of social justice" berpendapat bahwa keadilan adalah kebajikan utama dari hadirnya institusi-institusi sosial (social institutions). Secara spesifik, gagasan prinsip-prinsip keadilan dengan menggunakan konsep ciptaannya yang dikenal dengan "posisi asli" (original position) dan "selubung ketidaktahuan" (veil of ignorance) (Pan Mohamad Faiz, 2009. Sudjana, 2017).

Asas keadilan merupakan hal yang penting dalam pemungutan pajak sebagaimana dikemukakan oleh Santoso Brotodihardjo “"“...hukum pajak harus dapat memberikan jaminan hukum bagi tercapainya keadilan, dan jaminan ini diberikan kepada pihak-pihak yang tersangkut di dalam pemungutan pajak, yakni pihak fiscus dan wajib pajak" (Y. Sri Pudyatmoko, 2007) Sejalan dengan pendapat tersebut, Wiratni Ahmadi (2006), mengatakan: "agar dapat terpenuhi asas keadilan, maka hukum pajak menempuh suatu pola pemungutan pajak yang diselenggarakan secara umum dan merata. Artinya, seluruh individu-individu memiliki hak dan kewajiban yang sama dalam hukum pajak."

Pajak adalah kontribusi wajib kepada negara yang terutang oleh orang pribadi atau badan yang bersifat memaksa berdasarkan Undang-Undang, dengan tidak mendapatkan imbalan secara langsung dan digunakan untuk keperluan negara bagi sebesar-besarnya kemakmuran rakyat (UU No 28 Tahun 2007). Ketentuan Pasal 1 ayat (2) Undang-undang Nomor 28 Tahun 2007 tentang Ketentuan Umum dan Tata Cara Perpajakan, mengatur bahwa: "Wajib pajak adalah orang pribadi atau badan, meliputi pembayaran pajak, pemotong pajak, dan pemungut pajak, yang mempunyai hak dan kewajiban perpajakan sesuai dengan ketentuan peraturan perundangundangan perpajakan." Pajak penghasilan dikenakan terhadap penghasilan, yaitu setiap tambahan kemampuan ekonomis yang diterima atau diperoleh Wajib Pajak, baik yang berasal dari Indonesia maupun dari luar Indonesia, yang dapat dipakai untuk konsumsi atau untuk menambah kekayaan Wajib Pajak yang bersangkutan, dengan nama dan dalam bentuk apa pun (UU No 36 Tahun 2008).

Tarif pajak digunakan untuk menentukan besarnya pajak penghasilan yang terdiri dari 4 macam,yaitu: a. Tarif Sebanding/Proporsional; b. Tarif Tetap; c. Tarif Progresif; d. Tarif degresif (Rizka Novianti Pertiwi dkk, 2014). Selain itu dikenal tarif pajak bersifat final yaitu persentase tertentu dikalikan dengan laba bruto yang diterima oleh wajib pajak dalam tahun pajak berjalan. Konsekuensi PPh final yaitu: 
1. Tidak berlaku tarif progresif ;

2. Pemotongan PPh final tidak berlaku sebagai kredit pajak pada SPT Tahunan;

3. Tidak diperhitungkan sebagai pajak terutang;

4. Wajib dilaporkan dalam Surat Pemberitahuan Tahunan (SPT).

Pajak memiliki fungsi terdapat 2 (dua) yaitu: Fungsi budgetair; dan Fungsi mengatur (regulerend) (Mardiasmo, 2009). Sedangkan Tarif Pajak terdapat 4 macam: a. Tarif Sebanding/Proporsional b. Tarif Tetap c. Tarif Progresif d. Tarif degresif (Rizka Novianti Pertiwi, 2014). Selain itu dikenal tarif pajak bersifat final yaitu persentase tertentu dikalikan dengan laba bruto yang diterima oleh wajib pajak dalam tahun pajak berjalan.

Pedoman untuk menentukan prinsip keadilan dalam perundang-undangan menurut Adam Smith harus dipenuhi 4 (empat) syarat berikut (Rochmat Soemitro dan Dewi Kania Sugiharti, 2004): equality and equity; certainty; convienience of collection; dan economics of collections. Keempat pedoman ini disebut "the four canons of Adam Smith" atau " atau "the four maxim,"(Y. Sri Pudyatmoko, 2007. Suparnyo, 2012) yang penjabarannya sebagai berikut :

1. Equality atau kesamaan, mengandung arti bahwa keadaan yang sama atau orang yang berada dalam keadaan yang sama harus dikenakan pajak yang sama (Y. Sri Pudyatmoko, 2007). Dalam asas 'equality' ini tidak diperbolehkan suatu negara mengadakan diskriminasi di antara sesama wajib pajak. Dalam keadaan yang sama, para wajib pajak harus dikenakan pajak yang sama pula (Wiratni Ahmadi, 2006). Sementara itu, asas equity/kepatutan, merupakan keadilan yang bersifat khusus yang diterapkan pada suatu kasus tertentu (Syofrin Syofyan dan Asyhar Hidayat, 2004).

2. Certainty atau kepastian hukum, adalah tujuan setiap undang-undang (Soemitro dan Dewi Kania Sugiharti). UU Pajak yang baik senantiasa dapat memberikan kepastian hukum kepada wajib pajak, subjek dan objek pajak, besarya pajak, dan waktu pembayarannya (Oyok Abuyamin, 2010).

3. Convenience of payment, adalah pajak harus dipungut pada saat yang tepat, yaitu pada saat wajib pajak mempunyai uang atau saat sedekatdekatnya dengan detik diterimanya penghasilan yang bersangkutan (Oyok Abuyamin, 2010).

4. Economics of collection, dalam membentuk undang-undang pajak yang baru para konseptor wajib mempertimbangkan bahwa biaya pemungutan harus relatif lebih kecil dibandingkan dengan uang pajak yang masuk (Soemitro dan Dewi Kania Sugiharti).

Syarat pemungutan pajak adalah landasan prinsip yang harus ada dalam setiap aktivitas pemungutan pajak. Ada 5 syarat pemungutan pajak di Indonesia (https://www.online-pajak.com/syarat-pemungutan-pajak-ini-pengertian-dasarhukum-dan-penjelasannya).

a. Syarat Keadilan (pemungutan pajak harus adil).

b. Syarat Yuridis (pemungutan pajak harus berdasarkan undang-undang). 
c. Syarat Ekonomis (pemungutan pajak tidak mengganggu perekonomian nasional).

d. Syarat Finansial (pemungutan pajak harus efisien).

e. Syarat Sederhana (sistem pemungutan pajak harus sederhana).

Secara umum, model perpajakan usaha kecil dapat dibagi dalam dua kelompok besar, Kelompok pertama adalah sistem standard regime dan kedua sistem presumptive regime. Dalam standard regime, usaha kecil tidak dibedakan perlakuan perpajakannya. Namun demikian terdapat beberapa negara yang menerapkan standard regime dengan penyederhanaan formulir perpajakan, tata cara pembayaran, atau dengan pengurangan tarif. Negara-negara yang menerapkan standard regime untuk usaha kecil pada umumnya adalah negara-negara maju, yang komunitas usaha kecil nya telah memiliki efisiensi administrasi tinggi dan mempunyai kemampuan bookkeeping yang memadai (Kebijakan Pendapatan Negara-Badan Kebijakan Fiskal).

Sementara itu, dalam model presumptive regime, $\mathrm{PPh}$ dikenakan berdasarkan pada presumsi kondisi tertentu dari Wajib Pajak. Presumtive regime biasa digunakan terutama di negara di mana mayoritas pembayar pajaknya adalah kelompok yang susah untuk dipajaki ("hard to tax"), dan sumber daya adminstrasinya yang tidak memadai. Di negara tersebut sebagian besar wajib pajaknya tidak memiliki transparansi keuangan yang memungkinkan untuk pengenaan pajak secara efektif oleh pemerintah. Oleh karenanya, pemerintah perlu membuat perkiraan atau presumsi atas batasan pendapatan yang tepat untuk dikenai pajak. Presumptive regime lebih banyak diterapkan di negaranegara non-OECD. Regime ini pada umumnya digunakan dengan tujuan untuk meningkatkan compliance dan mendorong record keeping Wajib Pajak (Kebijakan Pendapatan Negara-Badan Kebijakan Fiskal). Penerapan presumptive regime pada umumnya menggunakan turnover based system, indicator based system, atau gabungan keduanya. Namun demikian di negara transisi, turnover system merupakan model yang umum digunakan.

Sebelum berlakunya PP 46 Tahun 2013, Indonesia menerapkan model standard regime dengan kemudahan dan fasilitas tertentu (standard regimesimplified/reduced rate). Kemudahan diberikan kepada Wajib Pajak Orang Pribadi (WP OP), sebagaimana di atur dalam Pasal 14 ayat (2) UU PPh, yaitu WP OP yang melakukan kegiatan usaha atau pekerjaan bebas yang peredaran brutonya dalam satu tahun kurang dari Rp4,8 miliar, diperkenankan untuk menggunakan Norma Penghitungan Penghasilan Neto (NPPN) dalam penghitungan penghasilan kena pajak nya. Sedangkan reduced rate diberlakukan untuk Wajib Pajak Badan, sebagaimana diatur dalam Pasal 31E UU PPh, bahwa WP Badan dalam negeri dengan peredaran bruto satu tahun sampai dengan Rp50 miliar, mendapat fasilitas berupa pengurangan tarif sebesar 50\% dari tarif normal PPh yang dikenakan atas Penghasilan Kena Pajak dari bagian peredaran bruto sampai dengan Rp4,8 miliar (Kebijakan Pendapatan Negara-Badan Kebijakan Fiskal).

Tarif PPh Final UKM yang ditetapkan oleh pemerintah sesuai dengan Peraturan Pemerintah (PP) Nomor 23 Tahun 2018 adalah sebesar 0,5\% yang dikenakan atas Peredaran bruto (omzet) usaha sebesar Rp 4,8 miliar dalam 1 tahun. Namun, meskipun pemerintah menurunkan tarif pajak final menjadi $0,5 \%$, namun beberapa UMKM tidak dapat memperkirakan omsetnya karena rendahnya disiplin dalam aktivitas pencatatan dan produksi UMKM berdasarkan pesanan. Ada masamasa ramai pesanan, namun juga ada masanya pesanan sepi. Kenaikan harga bahan bakar 
makin memperberat untuk memperoleh kuntungan, sedangkan melalui pajak final laba atau rugi bukan menjadi pertimbangan perhitungan pajak (Yuyung Rizka Aneswari, 2018).

Wajib pajak yang dikenakan PPh Final/pajak UKM dapat melakukan kompensansi kerugian dengan penghasilan yang tidak dikenai tarif $\mathrm{PPh}$ Final dengan ketentuan berikut:

a. Kompensasi kerugian dilakukan mulai tahun pajak berikutnya berturutturut sampai dengan 5 tahun pajak.

b. Kerugian suatu tahun pajak dikenakannya $\mathrm{PPh}$ Final tidak dapat dikompensasikan ke tahun pajak berikutnya.

Wajib pajak yang dikenakan tarif PPh Final / pajak UKM adalah:

a. Wajib Pajak orang pribadi atau Wajib Pajak badan yang tidak termasuk bentuk usaha tetap

b. Menerima penghasilan dari usaha, tetapi tidak termasuk penghasilan dari jasa yang berhubungan dengan pekerjaan bebas, dengan peredaran bruto (omzet) tidak melebihi Rp 4,8 miliar dalam 1 (satu) tahun pajak.

Tidak termasuk wajib pajak yang dikenakan PPh Final / pajak UKM adalah:

1. Wajib Pajak orang pribadi yang melakukan kegiatan usaha perdagangan dan/atau jasa yang dalam usahanya, yaitu:

a) Menggunakan sarana atau prasarana yang dapat dibongkar pasang, baik yang menetap maupun tidak menetap; dan

b) Menggunakan sebagian atau seluruh tempat untuk kepentingan umum yang tidak diperuntukkan bagi tempat usaha atau berjualan.

2. Wajib Pajak badan yang:

a) Belum beroperasi secara komersial; atau

b) Wajib Pajak badan yang dalam jangka waktu 1 (satu) tahun setelah beroperasi secara komersial memperoleh peredaran bruto (omzet) melebihi Rp 4,8 miliar.

Objek pajak PP 46 Tahun 2013 adalah pajak berdasarkan penghasilan dari usaha seperti usaha dagang, industri, dan jasa, seperti misalnya toko/kios/los kelontong, pakaian, elektronik, bengkel, penjahit, warung/rumah makan, salon, semua gerai/counter/outlet atau sejenisnya baik pusat maupun cabangnya dan lain-lain, yang diterima atau diperoleh wajib pajak dengan peredaran bruto (omzet) yang tidak melebihi Rp 4,8 miliar dalam 1 tahun pajak. Yang bukan objek pajak berdasarkan PP 46 Tahun 2013 adalah penghasilan dari jasa sehubungan dengan pekerjaan bebas, seperti misalnya: dokter, advokat/pengacara, akuntan, notaris, PPAT, arsitek, pemain musik, pembawa acara, dan sebagaimana dalam penjelasan Pasal 2 ayat (2) PP 46 Tahun 2013 dan penghasilan dari usaha dagang dan jasa yang dikenai PPh Final (Pasal 4 ayat (2), seperti misalnya sewa kamar kos, sewa rumah, jasa konstruksi (perencanaan, pelaksanaan dan pengawasan), $\mathrm{PPh}$ usaha migas, dan lain sebagainya yang diatur berdasarkan Peraturan Pemerintah. Non tax subject PP 46 adalah orang pribadi yang melakukan kegiatan usaha perdagangan dan atau jasa yang tidak memiliki lokasi permanen atau menggunakan sarana yang dapat dibongkar pasang dan menggunakan sebagian atau seluruh tempat untuk kepentingan umum misalnya pedagang keliling, pedagang asongan, warung tenda di area kaki-lima, dan sejenisnya (Lulu Setiawati, Josephine Kurniawati Tjahjono, 2015). 
Selanjutnya, PP No 46 Tahun 2013 diganti dan dicabut oleh PP No 23 Tahun 2018. Perbandingan kedua PP tersebut adalah (https://www.kawanpajak. com/2018/08/ perban- dingan-pp-46-vs-pp-23.html).

\begin{tabular}{|c|c|c|}
\hline & PP No 46 Tahun 2013 & PP No 23 Tahun 2018 \\
\hline Subjek Pajak & $\begin{array}{l}\text {-WP Orang Pribadi } \\
\text {-WP Badan tidak } \\
\text { termasuk BUT }\end{array}$ & $\begin{array}{l}\text {-Wajib Pajak Orang } \\
\text { Pribadi } \\
\text {-WP Badan tertentu } \\
\text { 1. PT } \\
\text { 2. CV dan Firma } \\
\text { 3. Koperasi }\end{array}$ \\
\hline $\begin{array}{l}\text { Pengecualian Subjek } \\
\text { Pajak }\end{array}$ & $\begin{array}{l}\text { Wajib Pajak orang pribadi } \\
\text { yang melakukan kegiatan } \\
\text { usaha perdagangan dan/atau } \\
\text { jasa yang dalam usahanya } \\
\text { menggunakan: } \\
\text { 3. sarana atau prasarana yang } \\
\text { dapat dibongkar pasang, } \\
\text { baik yang menetap } \\
\text { maupun tidak menetap; } \\
\text { dan sebagian atau seluruh } \\
\text { 4. sebat untuk kepentingan } \\
\text { tempat } \\
\text { umum yang tidak } \\
\text { diperuntukkan bagi } \\
\text { tempat usaha atau } \\
\text { berjualan aja } \\
\text { Wajib Pajak badan yang: } \\
\text { 3. belum beroperasi } \\
\text { secara komersial; atau } \\
\text { 4. dalam jangka waktu } 1 \\
\text { tahun setelah } \\
\text { beroperasi secara } \\
\text { komersial memperoleh } \\
\text { peredaran aruto } \\
\text { melebihi Rp4,8M }\end{array}$ & $\begin{array}{l}\text { 5. Wajib Pajak yang } \\
\text { memilih untuk dikenai } \\
\text { PPh berdasarkan tarif } \\
\text { Pasal } 17 \text { ayat (1) huruf } \\
\text { a, Pasal } 17 \text { ayat (2a), } \\
\text { atau Pasal 31E UU } \\
\text { PPh } \\
\text { 6. persekutuan } \\
\text { komanditer atau firma } \\
\text { yang dibentuk oleh } \\
\text { beberapa Wajib Pajak } \\
\text { orang pribadi yang } \\
\text { memiliki keahlian } \\
\text { khusus menyerahkan } \\
\text { jasa sejenis dengan } \\
\text { jasa sehubungan } \\
\text { dengan pekerjaan } \\
\text { bebas yang } \\
\text { 7. WP Badan yang } \\
\text { memperoleh fasilitas } \\
\text { Psl 31A UU PPh dan } \\
\text { PP 94 Bentuk Usaha Tetap }\end{array}$ \\
\hline Batasan Omzet & \multicolumn{2}{|c|}{$\begin{array}{l}\text { Menerima penghasilan dari usaha, tidak termasuk } \\
\text { penghasilan dari jasa sehubungan dengan pekerjaan bebas, } \\
\text { dengan peredaran bruto tidak melebihi Rp } 4,8 \mathrm{M} \text { dalam } 1 \\
\text { Tahun Pajak. }\end{array}$} \\
\hline
\end{tabular}




\begin{tabular}{|c|c|c|}
\hline $\begin{array}{l}\text { Pengecualian obyek } \\
\text { pajak }\end{array}$ & \multicolumn{2}{|c|}{$\begin{array}{l}\text { e. Penghasilan yang diterima atau diperoleh dari jasa } \\
\text { sehubungan dengan pekerjaan bebas; } \\
\text { f. Penghasilan yang diterima atau diperoleh diluar } \\
\text { negeri; } \\
\text { g. Usaha yang atas penghasilannya telah dikenai Pajak } \\
\text { Penghasilan yang bersifat final dengan ketentuan } \\
\text { peraturan perundang-undangan perpajakan tersendiri; } \\
\text { dan } \\
\text { h. Penghasilan yang dikecualikan sebagai objek pajak }\end{array}$} \\
\hline Tarif & $1 \%$ & $0,5 \%$ \\
\hline Batasan Waktu & Tidak ada & $\begin{array}{l}\text { 1. WP OP : } 7 \text { tahun } \\
\text { 2. CV/Firma/Koperasi: } 4 \\
\text { tahun } \\
\text { 3. PT : } 3 \text { tahun } \\
\text { dihitung sejak: } \\
\text { WP lama : Tahun Pajak } \\
\text { PP Berlaku } \\
\text { WP Baru :Tahun Pajak } \\
\text { terdaftar }\end{array}$ \\
\hline $\begin{array}{l}\text { Penentuan } \\
\text { Pengenaan Pajak }\end{array}$ & $\begin{array}{l}\text { Didasarkan pada peredaran } \\
\text { bruto dari usaha dalam } 1 \text { tahun } \\
\text { dari Tahun Pajak terakhir } \\
\text { sebelum Tahun Pajak yang } \\
\text { bersangkutan. }\end{array}$ & $\begin{array}{l}\text { Tetap. } \\
\text { Penegasan untuk WP OP } \\
\text { yang status Pisah harta } \\
\text { dan Memilih Terpisah (2 } \\
\text { NPWP) harus } \\
\text { berdasarkan } \\
\begin{array}{l}\text { penggabungan sesuai } \\
\text { prinsip keluarga sebagai } \\
\text { satu kesatuan ekonomis }\end{array}\end{array}$ \\
\hline DPP & Peredaran bruto tiap bulan & Peredaran bruto tiap bulan \\
\hline
\end{tabular}

Tarif pajak usaha kecil 0,5\% merupakan tarif opsional, artinya Wajib Pajak yang telah terdaftar sebagai WP PPh $0,5 \%$ dapat mengajukan permohonan ke DJP bahwa ingin mengikuti tarif PPh Skema Normal sesuai UU Pajak Penghasilan. Setelah mengajukan permohonan ke DJP, selanjutnya akan mendapatkan keterangan sebagai wajib pajak yang dikenai $\mathrm{PPh}$ yang mengacu pada pasal 17 Undang-Undang Nomor 36 Tahun 2008 tentang Pajak Penghasilan. Kebalikanya dengan hal diatas, bahwa wajib pajak yang sudah memilih untuk dikenai PPh dengan skema normal tidak dapat memilih untuk dikenai PPh Final 0,5\%. Tentang jangka waktu atau batasan waktu berlakunya PP 23 tahun 2018 sebagai pengganti PP 46 Tahun 213 ini sudah tertera 
pada tabel. Setelah batas waktu tersebut berakhir, WP akan kembali menggunakan skema normal seperti diatur oleh pasal 17 UU No.36. Hal ini bertujuan untuk mendorong wajib pajak menyelenggarakan pembukuan dan pengembangan usaha.

Faktor pertimbangan atas terbitnya Peraturan Pemerintah No 46 Tahun 2013 ini adalah adanya persepsi masyarakat yang menganggap tidak terdapat aspek keadilan. Pengenaan PPh yang bersifat final bermakna bahwa pelunasan PPh 1 persen dihitung dari peredaran bruto setiap bulan, kewajiban pajak atas penghasilan bersifat final. Ditinjau dari konsep keadilan dalam pemajakan (equity principle), pengenaan $\mathrm{PPh}$ Final tidak sesuai dengan keadilan karena tidak mencerminkan kemampuan membayar (ability to pay). Pemajakan yang adil adalah bahwa semakin besar penghasilan maka semakin besar pula pajak yang harus dibayar (the more you earn, the more you pay tax) (Endro Andayani,2018)

Melalui penelitian, Gerbing yang dikutip dalam Giligant dan Richardson (2005) mendefinisikan konsep dimensi keadilan pajak ke dalam lima variabel yaitu general fairness, exchange with the government, self interest, self provisions, dan tax rate structure. Kemudian dimensi keadilan pajak yang telah dikembangkan oleh Gerbing tersebut dijadikan acuan oleh beberapa peneliti dalam melakukan penelitian mengenai pengaruh dimensi keadilan pajak terhadap perilaku kepatuhan Wajib Pajak. Pada awalnya penelitian tersebut banyak dilakukan di negara barat, jarang peneliti menggunakan negara Asia sebagai objek penelitian. Giligant dan Richardson (2005) menyatakan bahwa perlu untuk melakukan penelitian-penelitian di negara lain untuk memperkaya pengetahuan tentang variabel keadilan pajak yang mempengaruhi perilaku kepatuhan.

\section{Penerapan Prinsip kepastian hukum dalam Pengenaan PPh final bagi Usaha Kecil}

Kepastian hukum didasarkan pada ajaran yuridis dogmatis bersumber pada aliran positivistik yang cenderung melihat hukum sebagai suatu yang otonom, mandiri karena hukum merupakan kumpulan aturan terlepas apakah adil atau tidak yang penting kepastian hukum terjamin. John Austin sebagai tokoh aliran positivisme mengatakan bahwa hukum terlepas dari keadilan dan baik-buruknya karena ilmu hukum bertugas menganalisis unsur-unsur yang secara nyata ada dalam sistem hukum modern. Ilmu hukum hanya berkaitan dengan hukum positif yaitu hukum yang diterima tanpa memperhatikan kebaikan dan keburukannya, karena hukum adalah perintah dari kekuasaan politik yang berdaulat daalm sebuah Negara (Satjipto Rahardjo, 2006:118). Hans Kelsen, berpendapat bahwa hukum adalah sebuah sistem norma. Norma adalah pernyataan yang menekankan aspek "seharusnya" atau das sollen, dengan menyertakan beberapa peraturan tentang apa yang harus dilakukan. Norma-norma adalah produk dan aksi manusia yang deliberatif. Undang-Undang yang berisi aturan-aturan yang bersifat umum menjadi pedoman bagi individu bertingkah laku dalam bermasyarakat, baik dalam hubungan dengansesama individu maupun dalam hubungannya dengan masyarakat. Aturan-aturan itu menjadi batasan bagi masyarakat dalam membebani atau melakukan tindakan terhadap individu, sehingga adanya aturan dan pelaksanaan aturan tersebut menimbulkan kepastian hukum (Peter Mahmud Marzuki, 2008).

Menurut Adolf Merkl, suatu norma hukum itu ke atas ia bersumber dan menjadi sumber bagi norma hukum di bawahnya sehingga suatu norma hukum itu 
mempunyai masa berlaku (rechtskracht) yang relatif oleh karena itu masa berlakunya suatu norma hukum itu tergantung pada norma hukum yang berada diatasnya sehingga apabila norma hukum yang berada diatasnya dicabut atau dihapus, maka norma-norma hukum yang berada dibawahnya tercabut dan terhapus pula (Maria Farida, 2006).

Berdasarkan teori Adolf Merkl tersebut, dalam teori jenjang normanya Hans Kelsen juga mengemukakan teorinya mengenai jenjang norma hukum (stufentheori), dimana ia berpendapat bahwa norma hukum- norma hukum itu berjenjang-jenjang dan berlapis-lapis dalam suatu hierarki tata susunan, dimana suatu norma yang lebih rendah berlaku, bersumber, dan berdasar pada norma yang lebih tinggi, norma yang lebih tinggi berlaku, bersumber dan berdasar pada norma yang lebih tinggi lagi, demikian seterusnya sampai pada suatu norma yang tidak dapat ditelusuri lebih lanjut dan bersifat hipotetis dan fiktif. Sehingga kaidah dasar diatas sering disebut dengan "grundnorm" atau "ursprungnorm" (Ni'matul Huda, 2008). Menurut Kelsen, grundnorm pada umumnya adalah meta juridisch, bukan produk badan pembuat undang-undang (de wetgeving), bukan bagian dari peraturan perundang-undangan, namun merupakan sumber dari semua sumber dari tatanan peraturan perundangundangan yang berada dibawahnya (Ni'matul Huda, 2008).

Norma dasar yang merupakan norma tertinggi dalam sistem norma tersebut tidak lagi dibentuk oleh suatu norma yang lebih tinggi lagi, tetapi norma dasar itu ditetapkan terlebih dahulu oleh masyarakat sebagai norma dasar yang merupakan gantungan bagi norma-norma yang berada dibawahnya sehingga suatu norma dasar itu dikatakan pre-supposed (Maria Farida Indrati Soeprapto, 2010). Dari uraian diatas mengenei ajaran Hans Kelsen, maka dapat disimpulkan bahwa: 1) Suatu tata kaedah hukum merupakan sistem kaedah-kaedah hukum secara hierarkis 2) Susunan kaedah hukum yang sangat disederhanakan dari tingkat terbawah ke atas 3) Sahnya kaedahkaedah hukum dari golongan tingkat yang lebih rendah tergantung atau ditentukan oleh kaedah-kaedah yang termasuk golongan tingkat lebih tinggi (http://repository.uin-suska.ac.id/7061/3/BAB\%20II.pdf).

Hukum positif Indonesia via UU No 12 Tahun 2011 tentang pembentukan peraturan perundang-undangan menerapkan pendapat kelsen ( Pasal 7 ).

(1). Jenis dan hierarki perundang-undangan terdiri atas:

a. Undang-Undang Dasar Negara Republik Indonesia Tahun 1945;

b. Ketetapan Majelis Permusyawaratan Rakyat

c. Undang-Undang/Peraturan Pemerintah Pengganti Undang-Undang;

d. Peraturan Pemerintah;

e. Peraturan Presiden;

f. Peraturan Daerah Provinsi; dan

g. Peraturan Daerah Kabupaten/Kota.

(2). Kekuatan hukum Peraturan Perundang-undangan sesuai dengan hierarki sebagaimana dimaksud pada ayat (1).

Pembentukan peraturan perundang-undangan merupakan sebuah proses yang menyangkut empat bentuk kegiatan, yaitu: pertama, prakarsa pembuatan undangundang; kedua, pembahasan rancangan undang-undang; ketiga, persetujuan atas pengesahan rancang undang-undang; dan keempat, persetujuan pengikatan atau ratifikasi atas perjanjian atau persetujuan internasional dan dokumen-dokumen hukum yang mengikat lainnya. Kata pembentukan undang-undang, merupakan rangkaian kata 
yang diartikan sebagai proses pembuatan undang-undang, yang kerangkanya dimulai dari perencanaan, persiapan, teknik penyusunan, perumusan, pembahasan, pengesahan, pengundangan, dan penyebarluasan. Secara terpisah, kata pembentukan juga diartikan sebagai proses, cara, atau perbuatan membentuk (Yuliandri, 2010).

Menurut Purnadi Purbacaraka dan Soerjono Soekanto dalam pembentukan peraturan perundangan-undangan harus memperhatikan asas- asas peraturan perundang-undangan antara lain Undang-undang yang dibuat oleh penguasa lebih tinggi mempunyai kedudukan yang tinggi pula (Lex superiori derogat legi inferiori); Undang-undang yang bersifat khusus akan mengesampingkan atau melumpuhkan undang-undang yang bersifat umum (Lex specialis derogat legi generalis) (Akmal Rudin, 2011).

Ketentuan tentang PPh final yang diatur dalam Pasal 4 ayat (2) huruf e UU No 36 Tahun 2008 yang kemudian dilaksanakan melalui PP No 46 Tahun 2013 yang diubah oleh PP No 23 Tahun 2018 secara yuridis bermasalah karena obyek PPh final lainnya dalam bentuk UU via Pasal 4 ayat (2) huruf a, b, c, d sedangkan huruf e nya diatur berdasarkan PP padahal obyek PPh final tersebut sederajat, sehingga seharusnya pengaturannya juga sederajat dalam bentuk UU. PP 23 Tahun 2018 sebagai amanat yang ditunjuk oleh Pasal 4 ayat (2) huruf e menjadi bias. Hal ini sejalan dengan pendapat A Hamid S Attamimi, karakteristik dari PP adalah Maria Farida Indrati Soeprapto, 2014: 99).

1. PP tidak dapat lebih dulu dibentuk tanpa ada UU yang menjadi induknya;

2. PP tidak dapat mencantumkan sanksi pidana apabila UU yang bersangkutan tidak mencantumkan sanksi pidana;

3. Ketentuan PP tidak dapat menambah atau mengurangi ketentuan UU yang bersangkutan;

4. PP dapat dibentuk meski ketentuan UU yang bersangkutan tidak memintanya secara tegas;

5. Ketentuan-ketentuan PP berisi peraturan atau gabungan peraturan dan penetapan. PP tidak berisi penetapan semata-mata.

Berdasarkan karakteristik dari PP poin 3 "Ketentuan PP tidak dapat menambah atau mengurangi ketentuan UU yang bersangkutan", maka penambahan kalimat dalam Pasal 4 ayat (2) UU No 36 Tahun 2008 huruf e "Penghasilan tertentu lainnya", yang diatur dengan atau berdasarkan Peraturan Pemerintah menjadi bertentangan dengan karakteristik PP itu sendiri sehingga mengakibatkan ketidak pastian hukum.

\section{KESIMPULAN}

Pengenaan PPh final bagi usaha kecil sejalan dengan asas kemanfaatan karena memudahkan WP usaha kecil untuk melunasi PPhnya tanpa harus membuat laporan keuanga secara detail, tetapi tidak sesuai dengan asas keadilan karena tidak memperhatikan daya pikul wajib pajak (usaha kecil yang bersangkutan) sebagaimana disyaratkan dalam undang-undang perpajakan, dan tidak konsisten sehingga tidak mencerminkan asas kepastian hukum mengingat pengaturan $\mathrm{PPh}$ final diatur dalam undang-undang via Pasal 4 ayat (2) huruf a s/d UU No 36 Tahun 2008 tentang pajak Penghasilan, selanjutnya penambahan obyek PPh final dalam Pasal 4 ayat (2) huruf e 
diatur melalui PP. Hal ini tidak sesuai dengan karakteristik PP yang tidak dapat menambah atau mengurangi ketentuan UU.

\section{SARAN}

Pengaturan tentang PPh final untuk usaha kecil perlu diatur dalam bentuk undang-undang, caranya dengan mengamandemen UU No 36 Tahun 2008 melalui penambahan pasal tentang PPh final untuk usaha kecil.

\section{UCAPAN TERIMA KASIH}

Penulis mengucapkan terimakasih kepada pihak-pihak yang telah membantu menyediaan materi untuk menyusun artikel ini, dan terimakasih juga kepada tim redaksi jurnal yang bersedia menerbitkan artikel ini.

\section{DAFTAR PUSTAKA}

\section{Buku}

Ahmadi, Wiratn. (2006). Perlindungan Hukum Bagi Wajib Pajak Dalam Penyelesaian Sengketa Pajak (Menurut UU Nomor 14 Tahun 2002 tentang Pengadilan Pajak), Bandung: PT. Refika Aditama.

Mardiasmo. (2009). Perpajakan. Edisi Revisi. Yogyakarta: Andi Offset.

Maria Farida (2006). Ilmu Perundang-Undangan Dasar-Dasar dan Pembentukannya, Yogyakarta: Kanikus.

Maria Farida Indrati Soeprapto.(2014). Ilmu Perundang-Undangan: Jenis, Fungsi, dan Materi Muatan. Yogyakarta: Kanisius.

Ni'matul Huda. (2008). UUD 1945 dan Gagasan Amandemen Ulang, Jakarta: Rajawali Press.

Oyok Abuyamin. (2010). Perpajakan Pusat \& Daerah.Bandung: Penerbit Humaniora.

Peter Mahmud Marzuki. (2008). Pengantar Ilmu Hukum, Jakarta: Kencana.

Rochmat Soemitro dan Dewi Kania Sugiharti (2004). Asas dan Dasar Perpajakan 1, Edisi Revisi, Bandung: PT. Refika Aditama.

Satjipto Rahardjo (2006), Ilmu Hukum, Bandung: Alumni 2006.

Syofrin Syofyan dan Asyhar Hidayat.(2004), Hukum Pajak dan Permasalahannya. Bandung: PT. Refika Aditama.

Utrecht/ Moh Saleh Djindang. tanpa tahun. Pengantar Dalam Hukum Indonesia. Jakarta: Pustaka Sinar Harapan.

Y. Sri Pudyatmoko, (2007). Pengantar Hukum Pajak . Edisi Revisi, Yogyakarta: Penerbit Andi.

Yuliandri. (2010). Asas-Asas Pembentukan Peraturan Perundang-Undangan Yang Baik, Jakarta : PT. Raja Grafindo. 


\section{Perundang-undangan}

Republik Indonesia. Undang-Undang Nomor 27 Tahun 2008 tentang Perubahan Ketiga Atas Undang-Undang Nomor 6 Tahun 1983 Tentang Ketentuan Umum dan Tata Cara Perpajakan.

Republik Indonesia. Undang-Undang Nomor 7 Tahun 1983 sebagaimana telah diubah oleh Undang-Undang Nomor 36 Tahun 2008 tentang Pajak penghasilan.

Republik Indonesia. Undang-Undang Nomor 12 Tahun 2011 tentang Pembentukan Peraturan Perundang-undangan.

Republik Indonesia. Undang-Undang Nomor 11 Tahun 2016 tentang Pengampunan Pajak.

\section{Jurnal, Makalah, dan sumber digital (Internet)}

Depri Liber Sonata. (2014). "Metode Penelitian Hukum Normatif Dan Empiris: Karakteristik Khas Dari Metode Meneliti Hukum", Fiat Justisia Jurnal Ilmu Hukum Volume 8 No. 1, Januari-Maret 2014. ISSN 1978-5186.

Endro Andayani. (2018). "Pengaruh Faktor-Faktor Pelaksanaan PP 46 Tahun 2013 Terhadap Kepatuhan Wajib Pajak UMKM (Studi Kasus UMKM Pusat Grosir Tanah Abang Jakarta Pusat)", Jurnal Transparansi Vol. 1, No. 1, Juni, pp. 1228, E-ISSN 2622-0253.

George Giligant and G. Richardson. (2005). ${ }^{\text {Perceptions of Tax Fairness and Tax }}$ Compliance in Australia and Hongkong - A Preliminary Studyee, Journal of Financial Crime; Aug 2005; 12, 4; Criminal Justice Periodicals.

Hendri (2018). "Implementasi Sosialisasi Peraturan Pemerintah No. 23 Tahun 2018 Bagi Pelaku Usaha Mikro, Kecil dan Menengah (UMKM)", Jurnal Vokasi Indonesia, Jul-Des | Vol.6 | No.2, hlm 54, file:///C:/Users/kiki/Downloads/127317-1-PB.pdf.

Lulu Setiawati, Josephine Kurniawati Tjahjono. (2015). "Pengaruh Penerapan Peraturan Pemerintah No. 46 Tentang PPh Final Terhadap Pajak Penghasilan Dan Profit PT.X”, Jurnal Gema Aktualita, Vol. 4 No. 1, Juni 2015.

Pan Mohamad Faiz. (2009). “Teori Keadilan John Rawls”, Jurnal Konstitusi, Volume 6 Nomor 1 (April).

Rizka Novianti Pertiwi Devi Farah Azizah Bondan Catur Kurniawan. (2014). "Analisis Efektivitas Pemungutan Pajak Bumi Dan Bangunan (Studi Pada Dinas Pendapatan, Pengelolaan Keuangan dan Aset Kota Probolinggo), Jurnal Perpajakan |Vol. 3 No. 1 November 2014| hlm 2, https://media.neliti.com/media/publications/193071-ID-analisis-efektivitaspemungutan-pajak-bu.pdf.

Sudjana. (2017). Penerapan Stelsel Konstitutif Terhadap Desain Industri Yang Cepat Berubah (Fast Moving) Berdasarkan Undang-Undang Nomor 31 Tahun 2000 Dihubungkan Dengan Perjanjian Trips-WTO, Jurnal Bina Mulia Hukum, hlm 121.Volume 1, Nomor 2, Maret 2017 P-ISSN: 2528-7273 E-ISSN: 2540-9034.

Tata Wijayanta. (2014). "Asas Kepastian Hukum, Keadilan dan Kemanfaatan Dalam Kaitannya Dengan Putusan Kepailitan Pengadilan Niaga”, Jurnal Dinamika 
Hukum Vol. 14 No. 2 Mei 2014. file:///C:/Users/kiki/Downloads/291-509-1PB.pdf.

Yuyung Rizka Aneswari1. (2018). Membongkar Imperialisme dalam Kebijakan Pajak Usaha Mikro Kecil dan Menengah (UMKM), Jurnal InFestasi Vol. 14 No. 1 Juni 2018, hlm 1. 1 - 10, file:///C:/Users/kiki/Downloads/4246-10109-1SM.pdf.

Aneswari, Y. R., Darmayasa, I. N., \& Yusdita, E. E. (2015). Perspektif Kritis Penerapan Pajak Penghasilan 1\% Pada UMKM. In Simposium Nasional Perpajakan 5 Fakultas Ekonomi- Universitas Trunojoyo Madura, 12 November 2015. Madura: Universitas Trunojoyo, 12 Nopember 2015.

IFC, 2007, Designing a Tax System for Micro and Small business, IFC-World Bank Group.

Pusat Kebijakan Pendapatan Negara-Badan Kebijakan Fiskal, Pengenaan PPh Final Untuk Wajib Pajak Dengan Peredaran Bruto Tertentu, Sebuah Konsep Kesederhanaan Pengenaan $\mathrm{PPh}$ Untuk Meningkatkan Voluntary Tax Compliance. $\quad$ https://www.kemenkeu.go.id/sites/ default/files/ kajian\%20pph\%20final\%20Usaha kecil_pkpn.pdf.

Suparnyo. (2012), Penerbit Pustaka Magister Semarang http://eprints.umk.ac.id/277/ 10/ Buku_Hukum_Pajak _Suatu_Sketsa_Asas_-_Indeks.pdf https://www.online-pajak.com/syarat-pemungutan-pajak-ini-pengertiandasar-hukum-dan-penjelasannya.

Www.Rappler.Com. (2017). Negara Menerima Rp 135 Triliun Dari Program Pengampunan Pajak. Retrieved February 22, 2018, From Https://Www.Rappler.Com/Indonesia/Berita /165803-Negara-Terima-Rp135TriliunProgram-Amnesti-Pajak.

https://www.kawanpajak.com/2018/08/perbandingan-pp-46-vs-pp-23.html

http://repository.uin-suska.ac.id/7061/3/BAB\%20II.pdf.

Akmal Rudin, Analisis Yuridis Tentang Kembalinya Ketetapan Majelis Permusyawaratan Rakyat (TAP MPR) Dalam Hierarki Peraturan Perundangundangan Di Indonesia (Studi Yuridis Pasal7 UU No. 10 Tahun 2004 dengan Pasal 7 UU No. 12 Tahun 2011) http://repository.uin suska.ac.id/7061/3/BAB\%20II.pdf, hlm 32. 